\title{
Tedarik Zinciri Riskleri'nin Lojistik Performans Üzerindeki Etkisinin Yapısal Eşitlik Modellemesi ile Belirlenmesi
}

\begin{abstract}
Mert Özgüner ${ }^{1}$
Zeynep Özgüner ${ }^{2}$

Tedarik Zinciri Riskleri'nin Lojistik Performans Üzerindeki Etkisinin Yapısal Eşitlik Modellemesi ile Belirlenmesi

Öz

Teknoloji ve telekomünikasyon alanında meydana gelen hızlı değişim, bilgi ve veri paylaşımının artan önemi, ekonomik gelişmeler, iş ve sosyal yaşamda meydana gelen değişiklikler, pazarda meydana gelen hızlı değişim belirsizlikleri artırmakta ve işletmelerin daha fazla riskle karşı karşıya kalmalarına neden olmaktadır. İşletmelerin de içerisinde bulunduğu tedarik zincirlerinde karşılaşılacak muhtemel riskler, zincirin tüm halkalarını olumsuz etkileyebilmekte ve işletmelerin performanslarının düşmesine yol açabilmektedir. Bu çalışmada işletmelerin karşılaşabileceği muhtemel tedarik zinciri risklerinin lojistik performans üzerindeki etkileri Yapısal Eşitlik Modeli ile test edilmiştir. Bu kapsamda hazırlanan anket Gaziantep Organize Sanayi Bölgeleri'nde faaliyet gösteren üretim işletmeleri üzerinde uygulanmıştır. Elde edilen bulgular işletmelerin tedarik zinciri risklerine ait bazı alt boyutların lojistik performans üzerinde negatif

Determining The Effect of Supply Chain Risks on Logistic Performance with Structural Equation Modeling

Abstract

Rapid change in the field of technology and telecommunications, increasing importance of information and data sharing, economic developments, changes in business and social life, the rapid change in the market increases the uncertainties and causes businesses to face more risks. Possible risks to be encountered in the supply chains in which the enterprises are located may adversely affect all the chains of the chain and may cause the performance of the enterprises to decrease. In this study, the effects on the logistic performance of potential supply chain risks that businesses may encounter have been tested with the Structural Equation Model. In this context, the prepared questionnaire has been tested on the production enterprises operating in Gaziantep Organized Industrial Zones. The findings reveal that some subdimensions of supply chain risks of businesses have a negative and significant effect on logistic performance.
\end{abstract} ve anlamlı bir etkisinin olduğu sonucunu ortaya koymaktadır.

Anahtar Kelimeler Tedarik Zinciri Riskleri, Lojistik Performans, Yapısal Eşitlik Modeli

Keywords: Supply Chain Risks, Logistic Performance, Structural Equation Model

\section{Giriş}

Teknolojik gelişmelerin hızla yaşandığı günümüz küresel dünyasında özellikle bilgi ve telekomünikasyon alanındaki gelişmeler gerek tüketicilerin satın alma davranışları, talep ve beklentileri üzerinde gerekse de rekabet üzerinde önemli değişiklikler meydana getirmiştir. Şiddetli rekabetin hâkim olduğu ortamda var olmak isteyen işletmeler ürettikleri mal veya hizmetleri olabildiğince hızlı, kaliteli, esnek ve düşük maliyetlerle müşterilerine ulaştırmak zorunda kalmıştır. Bu zorunluluk işletmeleri gerek tedarikçilerine gerekse de aracılarına her geçen gün daha da yakınlaştırmıştır. Böylece tedarik zincirinin önemi artmış, işletmelerin başarısı içerisinde bulundukları tedarik zincirinin başarısına bağlı hale gelmiştir. Tedarik zincirinin başarılı bir şekilde yönetilmesi gerek lojistik performansın gerekse de işletme performansının artırılması noktasında çok büyük bir öneme sahiptir.

\footnotetext{
1 Dr. Öğr. Üyesi, Adıyaman Üniversitesi, Besni Meslek Yüksekokulu, Yönetim Ve Organizasyon Bölümü, mozguner@adiyaman.edu.tr, ORCID: https://orcid.org/0000-0003-4919-9391

2 Dr. Öğr. Üyesi, Hasan Kalyoncu Üniversitesi, İktisadi, İdari Ve Sosyal Bilimler Fakültesi, İşletme Bölümü, zeynep.ozguner@hku.edu.tr, ORCID: https://orcid.org/0000-0002-8694-7275
} 
Işletmeler için hayati öneme sahip olan tedarik zincirleri gerek küresel gerekse bölgesel olmak üzere birçok riskle karşı karşıyadır. Özellikle son yıllarda yaşanan politik ve çevresel tehditler gerek hammadde tedarikinde gerekse üretilen mal ve hizmetlerin pazarlara ulaştırılması noktasında çok büyük sorunları da beraberinde getirmektedir. Bununla birlikte ekonomik belirsizlikler, iş̧̧i kaynaklı sorunlar, engellenemeyen doğal afetler, teknolojik riskler işletmelerin faaliyetlerinin daralmasına ve performanslarının azalmasına neden olabilmektedir. Bu risklerin özellikle işletmelerin lojistik performansları üzerinde oluşturacağı baskı tedarik zincirinde iş akışlarının önünü kesecek, gecikmeleri artıracak ve büyük performans kayıplarına neden olacaktır.

Bu araştırmada işletmelerin tedarik zinciri risklerini ne düzeyde algıladıkları ve algıladıkları bu risklerinin lojistik performans üzerinde nasıl bir etkiye sahip olduğu belirlenmeye çalışılmıştır. Araştırma sonuçlarıyla birlikte işletmelerin başarısı üzerinde etkisi olduğu düşünülen tedarik zinciri risklerinin önemi ortaya konulacak ve işletmelerin bu risklerle mücadele edebilmeleri noktasında nasıl bir pozisyon alabilecekleri noktasında somut bir takım çıkarımlar ortaya konulacaktır.

\section{Kavramsal Çerçeve}

\subsection{Tedarik Zinciri Riskleri}

Risk, gelecekte karşılaşılabilecek olan ve amaçlar ulaşılmasını engelleyebilecek tehdit, olumsuzluklar veya amaçlara ulaşmayı kolaylaştıracak fırsatlardır (Derici vd., 2007: 152). Bunun yanında işletmeler açısından risk kazanmaktan ziyade kaybetme olasılığı olarak değerlendirilmektedir. Birçok araştırmacı riskin bir olayın potansiyel, beklenmeyen olumsuz sonuçları olduğunu vurgulamıştır (Fitrianto ve Hadi, 2012: 429). Tedarik zinciri riski ise, ilk tedarikçiden nihai tüketiciye kadar geçen süreçte bilgi, malzeme ve akışı ile ilgili her türlü riski kapsamaktadır (Jüttner vd., 2003: 200). Zsidisin ve Wagner (2008: 402-403)' e göre tedarik zinciri riski; işletmelerin pazarın istek ve beklentilerini karşılama yeteneğini azaltan veya müşterinin devamlılı̆ını tehlikeye atan, gerek tedarikçiden gerekse sektörün içerisinde bulunduğu genel durumdan kaynaklanan ve sonucunda birtakım mali kayıplar doğuran risklerdir.

Özellikle son yıllarda dünyada meydana gelen sel de dâhil doğal felaketler, tsunami ve depremler, küresel çapta yaşanan toplumsal çatışmalar ve sektörel belirsizlikler, tedarik zinciri içerisinde yaşanan hata ve bozukluklar işletmelerin bu konuya olan ilgisini artırmış ve bunun sonucu olarak tedarik zinciri riskleri işletmelerin refahının ve devamlılığının merkezinde yerini almıştır (Narasimhan ve Talluri, 2009: 114; Ghagde vd., 2012: 313).

Teknoloji ve telekomünikasyon alanındaki hızlı değişim işletmeleri rekabet üstünlüğü sağlama noktasında rakiplerinden daha hızlı olmaya mecbur hale getirmiştir. Bununla birlikte bilgeye kolay ulaşmanın bir sonucu olarak müşteri beklentilerinde meydana gelen hızlı değişim ve çeşitlilik çevresel belirsizlikleri artırmış ve işletmeleri birçok riskle karşı karşıya bırakmıştır (Chatzidimitriou vd., 2008: 591). Bununla birlikte Ar-Ge maliyetlerinin artması, tedarikçi ilişkileri, artan teknoloji bağımlılı̆ı, yasal gereklilikler ve artan üretim maliyetleri tedarik zinciri yapılarının karmaşık hale gelmesine neden olmuş ve bu da tedarik risklerinin artmasına yol açmıştır (Wagner ve Neshat, 2010: 121).

Tedarik zinciri riskleri işletmelerin kısa ve uzun vadede ulaşmak isteği hedefleri büyük ölçüde etkilediği yaşanmış birçok örnek olaydan da anlaşılmaktadır. Örneğin, Amerikan Havayolu şirketinin taşıdığı et, ilaç yem gibi bozulma olasılığı yüksek ürünlerin taşınması esnasında yaşadığı gecikme problemi bu ürünlerin tamamının bozulması ve toplatılması ile sonuçlanmış 
ve bu olaya havayolu şirketinin çok büyük maddi kayıp yaşamasına neden olmuştur (Salkın, 2014: 13). Benzer şekilde Toyota ve Honda gibi dev otomotiv firmalarının 2011 yılında yaşanan tsunami felaketi nedeniyle yaşadığı tedarik sorunları tedarik zinciri risklerine örnek olarak verilebilir (Demirkol vd., 2015: 21).

Tedarik zinciri riskleri ile ilgili olarak yapılan çalışmalarda uzmanlar tarafından birçok risk faktörünün olduğu ortaya çıkarılmıştır. Eriksson vd., (2014: 1080)'ne göre fiyat dalgalanmaları, teknolojik gelişmeler ve kalite problemlerinin tedarik zincirinde meydana gelebilecek risklerin temel nedenleri olarak görülmektedir. Büyüközkan (2018:1-5) tedarik zinciri riskleri ile ilgili yaptığı sınıflandırmada bu risklerin 4 guruba ayrıldığını ve bu risk guruplarının; tedarikçi kaynaklı riskler, üretici kaynaklı riskler, müşteri kaynaklı riskler ve çevresel faktörlerin etkisiyle gelişen riskler olduğunu belirtmiştir. Tedarik zinciri riskleri ile ilgili olarak Dünya Ekonomik Formu tarafından 2012 yılında yapılan araştırma sonucunda ortaya çıkan risk sınıflandırması Tablo 1 'de sunulmuştur.

Tablo 1: Dünya Ekonomik Formu Tedarik Zinciri Risk Sınıflandırması

\begin{tabular}{|c|c|c|}
\hline Risk Kaynağı & Riskler & Görülme Yüzdesi \\
\hline \multirow{3}{*}{ Çevresel Riskler } & Doğal afetler & $\% 59$ \\
\hline & Kötü hava şartları & $\% 30$ \\
\hline & Salgın hastalıklar & $\% 11$ \\
\hline \multirow{7}{*}{ Jeopolitik Riskler } & Çatışma ve politik huzursuzluk & $\% 46$ \\
\hline & İthalat/ihracat sınırlamaları & $\% 33$ \\
\hline & Terörizm & $\% 32$ \\
\hline & Yolsuzluk & $\% 17$ \\
\hline & Korsan ticaret ve organize suç & $\% 15$ \\
\hline & Deniz korsanlığı & $\% 9$ \\
\hline & Nükleer/kimyasal /biyolojik silahlar & $\% 6$ \\
\hline \multirow{7}{*}{ Ekonomik Riskler } & Ani talep şokları & $\% 44$ \\
\hline & Ürün fiyatlarında fazla dalgalanma & \\
\hline & Gümrük gecikmeleri & $\% 26$ \\
\hline & Kur dalgalanmaları & $\% 26$ \\
\hline & Küresel enerji darlığı & $\% 19$ \\
\hline & Mülkiyet/yatırım sınırlamaları & $\% 17$ \\
\hline & İşgücü eksikliği & $\% 17$ \\
\hline \multirow{2}{*}{$\begin{array}{l}\text { Teknolojik } \\
\text { Riskler }\end{array}$} & Bilgi ve haberleşme kesintileri & $\% 30$ \\
\hline & Taşımacılık altyapısı yetersizliği & $\% 6$ \\
\hline
\end{tabular}

Kaynak: World Economic Forum Supply Chain and Transport Risk Survey, 2012: 8.

Dünyanın önde gelen işletmeleri de dâhil olmak üzere birçok işletmenin tedarik zincirinde üretim, satış ve dağıtım faaliyetlerinde yukarıda bahsi geçen birçok riskle karşılaştığını ve bu risklerle mücadele etmekte zorlandı̆̆ını söylemek mümkündür. Bu riskleri etkin bir şekilde yönetemeye işletmeler gerek fiziksel ve finansal gerekse de psikolojik ve sosyal açıdan çok önemli kayıplara maruz kalabilmektedir (Ellis vd., 2010: 36). 


\subsection{Lojistik Performans}

Yoğun rekabetin hâkim olduğu günümüz koşullarında işletmelerin performanslarını artırmaları noktasında performans yönetimi oldukça öneli bir hal almıştır. İşletmeler ekonomik açıdan değerlendirilebilen tüm faaliyetlerinde performans kavramını odak nokta haline getirmiştir (Kayabaşı ve Özdemir, 2008: 198). Performans, görevler doğrultusunda önceden belirlenmiş kriterleri karşılayacak şekilde, bir görevin yerine getirilmesi ve amacın gerçekleştirilmesi doğrultusunda ortaya konan mal, hizmet veya düşüncedir (Helvacı, 2012: 156).

Günümüzde özellikle işletmelerin performansları üzerinde önemli bir rolü olan lojistik faaliyetler noktasında da performans kavramı önem taşımaktadır. Yüksek performansa sahip lojistik süreçler arzu edilen müşteri seviyesinin sağlanması ve toplam dağıtım maliyetlerinin minimizasyonu sayesinde verimliğin artmasına, üretim ve dağıtım sürecinde bilgi ve malzeme akışının sağlıklı bir biçimde yapılmasına imkân sağlayacaktır (Paksoy vd., 2003: 4). Lojistik performans; önceden belirlenmiş lojistik faaliyetlerin belirli bir süre sonunda ortaya çıkan sonuçlarının gerek nitel gerekse nicel anlamda tanımlanmasıdır (Bakan ve Şekkeli, 2015: 44). Bayraktutan ve Özbilgin (2015: 98)'e göre lojistik performans; lojistik hizmetlerin kalitesi ile mal veya hizmetlerin müşterilere hızlı bir şekilde ulaştırılmasını ifade etmekte ve lojistik faaliyetlerin başarı ve etkinliğinin bir ölçüsü olarak kabul edilmektedir. Lojistik performans, lojistik hizmet kalitesi, lojistik maliyetler, müşteri tatmini, mal veya hizmetin pazarda bulunabilirliği, tam zamanında teslimat oranı, taşımadan kaynaklı hasar oranları, esneklik ve stok verimliliği gibi konularla değerlendirilmektedir (Sezen vd., 2002: 134). Lojistik performans, lojistik hizmetlerin sektörde gerçekleşen, değişen ve çeşitlenen talepleri yerine getirebilme yeteneği olarak ifade edilebilmektedir (Bayraktutan ve Özbilgin, 2015: 98).

Literatür incelendiğinde lojistik performansın kalite, müşteri memnuniyeti, maliyet ve esneklik olmak üzere dört temel gösterge üzerinde değerlendirildiği görülmektedir (Özgüner, 2017: 84). Bakan ve Şekkeli (2015: 45)'ye göre lojistik performans; ürünlerin sipariş ve çevrim sürelerinin uzunluğu, üreticilerin teslim tarihleri ile ilgili performansları, sözlerine bağlılıkları, stok seviyeleri, transit süreleri ve tarifeleri, malzeme koordinasyonu, kayıp ve hasar düzeyleri ile ölçülebilmektedir. Bazı araştırmacılar lojistik performansın ölçümü noktasında lojistik süreçlerin önemine vurgu yapmış ve lojistik süreç temelinde geçerlilik, tekrar uygulanabilirlik, yararlılık, bütünlük, ekonomiklik, uyumluluk ve çalışanların bireysel etkisi şeklinde birçok ölçüt ortaya koymuştur (Kayabaşı ve Özdemir, 2008: 200).

\subsection{Tedarik Zinciri Riskleri'nin Lojistik Performansa Etkisi}

Artan rekabet koşulları ile birlikte işletmeler üzerinde oluşan şiddetli baskı işletmelerin devamlılıklarını koruyabilmeleri adına gerek talep gerekse tedarik ve işletme içi belirsizlikleri tahmin etme noktasında daha fazla kaynak tüketmeye zorlamıştır. Bu durum işletmelerin daha fazla riskle karşı karşıya kalmalarına ve performans kayıplarına yol açabilmektedir (Akkan, 2014: 27).

Küresel yapı içerisinde işletmeler deprem, yangın, terör, savaş, planlama, kapasite, ürün gibi birçok riskle karşı karşıya kalabilmektedir. Karşılaşılması muhtemel bu riskler işletmelerin faaliyetlerinin aksamasına hatta durmasına yol açabilmekte ve bu da işletmelerin rekabet güçlerini kaybetmelerine neden olabilmektedir. Dereli (2014: 25)'e göre tedarik zincirinde; belirsiz ekonomik koşullar, müşteri taleplerindeki beklenmedik iptaller, tahmin edilemeyen afetler hem kısa vadede hem de uzun vadede işletmelerin performanslarını olumsuz şekilde etkilemektedir. Bu riskler işletmelerin maliyet, kalite ve zaman unsurlarını kontrol edememe- 
lerine yol açarak büyük performans kayıplarına yol açmaktadır. Yaşanan bu performans kayıplarının yanında işlerin kesintiye uğraması, ürün kalitesinin azalması, teslimatların gecikmesi gibi lojistik sorunları da beraberinde getirmektedir (Kırılmaz, 2014: 28). Bu açıklamadan da anlaşılacağı üzere özellikle lojistik performans göstergeleri arasında yer alan kalite, esneklik ve hız üzerindeki olumsuz etkileri göz önüne alındığında, tedarik zinciri risklerinin lojistik performans üzerinde olumsuz etkilerinin olduğunu söylemek mümkün olmaktadır.

Haksöz vd. (2014: 306)'ne göre tedarik zinciri riskleri işletmelerin finansal ve genel performansı üzerinde doğrudan etkiye sahiptir. Bununla birlikte bu riskler malzeme, bilgi, nakit akışlarını ciddi şekilde aksatıp geciktirmektedir. Bu durum lojistik süreçlerin aksaması anlamına gelecek ve işletmelerin karlılıklarını, verimliliklerini azaltacaktır. Jüttner vd. (2003: 205) tedarik zinciri risklerinin mal veya hizmetlerin nihai tüketiciye ulaştırılması noktasında işletmelere engel teşkil etmektedir. Örneğin, Boeing firmasının üretim çizelgelerinde yaşadığı yı̆̆ılma problemleri nedeniyle siparişlerin 15 ay gecikmeli ulaştırılacağını açıklaması müşterilerde çok ciddi hayal kırıklıkları oluşturmuş ve ciddi kayıplara neden olmuştur (Salkın, 2014: 13).

İyi planlanmamış lojistik süreçler, tedarik zinciri risklerinin de etkisiyle arz esnekliğinin azalmasına ve talebin karşılanmasında aksamalara neden olabilmektedir. Bu da işletmelere oldukça büyük maliyet yüklemekte, tedarik ve lojistik sorunlarını artırmaktadır (Wagner ve Neshat, 2010: 121). İşletmeler, etkin bir şekilde planlanan lojistik süreçlerle sayesinde yeteneklerini ve hızlarını artıracak, çevik bir yapıya bürünerek hem tedarik zinciri risklerinin olumsuz etkilerini azaltılacak hem de işletme performansını artıracaktır (Ishtiaqıshaq vd., 2012: 90).

Bu açıklamalar ışığında tedarik zinciri risklerinin lojistik performans üzerinde beklenen etkilerini test etmek maksadıyla aşağıdaki hipotezler geliştirilmiştir.

H1: Kapasite ve Tedarik Riski ters yönlü ve anlamlı olarak etkiler.

H2: Teknolojik Riskler ters yönlü ve anlamlı olarak etkiler.

H3: Ürün Riski ters yönlü ve anlamlı olarak etkiler.

H4: Tahmin ve Planlama Riski ters yönlü ve anlamlı olarak etkiler.

H5: Gecikme Riski ters yönlü ve anlamlı olarak etkiler.

H6: Kesinti Riski ters yönlü ve anlamlı olarak etkiler.

H7: Politik Riskler ters yönlü ve anlamlı olarak etkiler.

H8: Envanter Riski ters yönlü ve anlamlı olarak etkiler.

\section{Araştırmanın Yöntemi}

\subsection{Araştırmanın Amacı ve Önemi}

$\mathrm{Bu}$ çalışma, tedarik zincirinde karşılaşılan risklerin üretim işletmelerinin lojistik performansları üzerindeki etkisini belirlemeyi amaçlamaktadır. Bu kapsamda ilk olarak Gaziantep Organize Sanayi Bölgesi'nde faaliyet gösteren 250 üretim işletmesinin tedarik zinciri risklerini algılama düzeyleri belirlenmiş ve daha sonra bu risklerin işletmelerin lojistik performansları üzerinde nasıl bir etkiye sahip olduğu yapılan Yapısal Eşitlik Modeli analizi ile ortaya konulmuştur.

Özellikle işletmelerin başarısının tedarik zincirinin diğer halkalarına bağlı olduğu günümüz rekabet koşullarında tedarik zincirinde karşılaşılacak risklerin algılanma düzeylerini belirlemek işletmeler adına büyük önem taşımaktadır. Gerek işletmelerin lojistik faaliyetleri üzerinde gerekse performansları üzerinde önemli etkilerinin olabileceği düşünülen bu riskler hakkında işletmelerin bilgi sahibi olması, bu risklerin olumsuz etkilerinin minimuma indirilmesi noktasında faydalı olacaktır. 


\subsection{Araştırmanın Yöntemi}

Tedarik zinciri risklerinin lojistik performans üzerindeki etkisini belirlemeye yönelik olan bu araştırmada; Gaziantep Organize Sanayi Bölgesi'nde faaliyetlerini sürdürmekte olan üretim işletmelerinden edilen veriler $(n=250)$ ışığında oluşturulan modele (Şekil 1) ilişkin analizler yapılmıştır. Bu kapsamda ilk olarak elde edilen veriler Keşfedici Faktör Analizi'ne (KFA) tabi tutulmuştur. Daha sonra araştırmada kullanılan ölçeklerin araştırma verilerine uygunluğunu test etmek amacıyla Doğrulayıcı Faktör Analizleri (DFA) yapılmıştır. Yapılan KFA ve DFA'ların ardından araştırmanın sorunsalı kapsamında oluşturulan model Yapısal Eşitlik Modellemesi (YEM) analizi ile test edilmiştir. Araştırma Modeli Şekil 1'de sunulmuştur.

\section{Şekil 1: Araştırma Modeli}

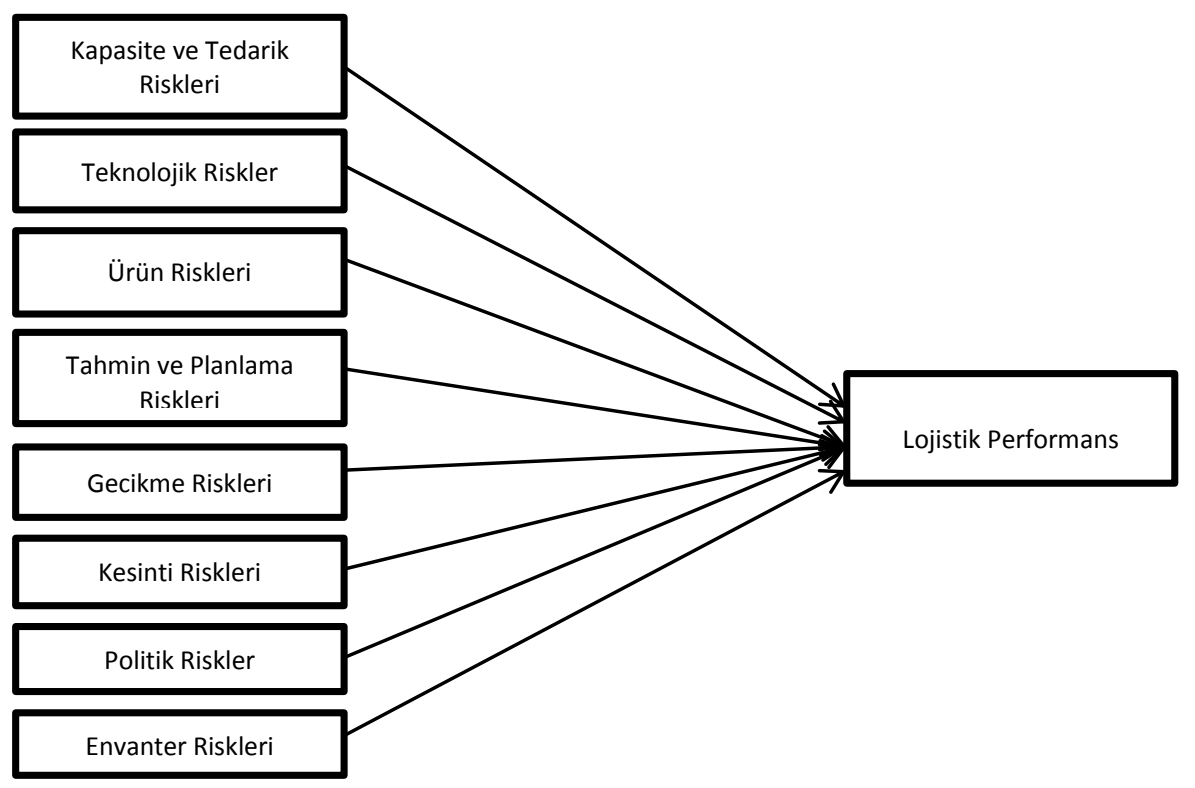

\subsection{Araştırmanın Evreni}

Araştırma evrenini Gaziantep Organize Sanayi Bölgesi'nde faaliyetlerini sürdürmekte olan üretim işletmeleri oluşturmaktadır. Söz konusu OSB' de yaklaşık 950 üretim işletmesi faaliyetlerini sürmektedir (www.gaosb.org). Ana kütleden \%95 güvenilirlik sınırları içerisinde \%5'lik bir hata payı dikkate alınarak minimum örneklem büyüklüğünün 274 işletme olarak hesap edilmiştir (Sekaran, 1992:253). Fakat gerek anketin uygulanacağı üst düzey yöneticilerin işletmelerde bulunamaması gerekse de bazı işletmeler tarafından anketin doldurulmak istenilmemesi, bazıları tarafından da anketlerin eksik doldurulduğunun tespit edilmesi üzerine toplamda 250 üretim işletmesinin verileri analize dâhil edilmiştir.

Araştırma kapsamında hazırlanan ölçek işletmelerde bulunan üst düzey yöneticilere ve tedarik ve lojistik sorumlusu olan orta düzey yöneticilere uygulanmıştır. Araştırmanın örneklemi belirlenirken basit tesadüfi örneklem yöntemine başvurulmuştur. Bu yönteme sayesinde belirlenen evren içerisindeki tüm üretim işletmelerine eşit düzeyde örnekleme girme şansı verilmektedir. Ayrıca küçük ölçekli evrenler için en işlevsel yöntemlerden biridir (Gürbüz ve Şahin, 2016: 138). 


\subsection{Araştırmanın Ölçekleri}

\subsubsection{Tedarik Zinciri Risk Ölçeği (TZRÖ)}

İşletmelerin tedarik zinciri risklerini algılama düzeyini belirlemek maksadıyla Chopra ve Sodhi (2004) tarafından geliştirilen ve Özgüner (2017) tarafından uygulanan güvenilirliği ve geçerliliği kanıtlanmış 29 sorudan oluşan ölçek kullanılmıştır. Ölçek 5'li Likert tipi ifadelerden oluşmaktadır (1=Çok Düşük, 5= Çok Yüksek).

Ölçeğin yapısal geçerliliğini ölçmek amacıyla öncelikle Keşfedici Faktör Analizi (KFA) yapılmıştır. KFA sonucunda TZR1, TZR11 VE TZR16 ifadeleri çapraz yüklenme nedeniyle ölçekten sırasıyla çıkarılmış ve her soru çıkarma işleminin ardından KFA yinelenmiştir. Yinelenen KFA sonucunda 26 ifadenin 8 boyut altında toplandığı görülmüştür. Örneklem yeterliliğinin belirlenmesi maksadıyla yapılan KMO ve Bartlett's testi sonucunda KMO değeri 0.717 ve Bartlett's testi anlamlı olarak bulunmuştur. Dağlı, 2015: 205)'ya göre KMO değerinin 0.60 ve üzerinde bir değer alması faktör analizi için yeterlidir.

Keşfedici faktör analizi sonucunda 8 faktörden oluşan ve toplam varyansın \%64,640'ını açıklayan bir yapı elde edilmiştir. Elde edilen yapıya ait faktör yüklerinin 0,386 ile 0,822 arasında olduğu görülmüştür. Gürbüz ve Şahin (2016: 312)'e göre çok boyutlu ölçeklerde tüm faktörlerin açıkladığı toplam varyansın en az \%50 olması önerilmektedir.

Tablo 2: Tedarik Zinciri Risk Ölçeği'ne Ait ifadelerin Faktör Yükleri

\begin{tabular}{|c|c|c|c|c|c|c|c|c|}
\hline & \multicolumn{8}{|c|}{ Döndürülmüş Bileşenler Matrisi } \\
\hline & \multicolumn{8}{|c|}{$\begin{array}{c}\text { Bileşenler } \\
\end{array}$} \\
\hline & $\begin{array}{l}\text { Kapasite ve } \\
\text { Tedarik Riski }\end{array}$ & $\begin{array}{l}\text { Teknolojik } \\
\text { Riskler }\end{array}$ & Ürün Riski & $\begin{array}{c}\text { Tahmin ve } \\
\text { Planlama } \\
\text { Riski }\end{array}$ & Gecikme Riski & Kesinti Riski & Politik Riskler & $\begin{array}{c}\text { Envanter } \\
\text { Riski }\end{array}$ \\
\hline TZR3 & ,554 & & & & & & & \\
\hline TZR6 & 687 & & & & & & & \\
\hline TZR8 & ,786 & & & & & & & \\
\hline TZR17 & ,368 & & & & & & & \\
\hline TZR18 & 797 & & & & & & & \\
\hline TZR29 & ,686 & & & & & & & \\
\hline TZR12 & & ,861 & & & & & & \\
\hline TZR13 & & 889 & & & & & & \\
\hline TZR14 & & 811 & & & & & & \\
\hline TZR23 & & & 864 & & & & & \\
\hline TZR25 & & & 867 & & & & & \\
\hline TZR15 & & & & 638 & & & & \\
\hline TZR21 & & & & ,745 & & & & \\
\hline TZR28 & & & & ,637 & & & & \\
\hline TZR7 & & & & & 631 & & & \\
\hline TZR9 & & & & & ,718 & & & \\
\hline TZR10 & & & & & ,763 & & & \\
\hline TZR2 & & & & & & ,520 & & \\
\hline TZR19 & & & & & & 386 & & \\
\hline TZR20 & & & & & & 813 & & \\
\hline TZR22 & & & & & & ,622 & & \\
\hline TZR4 & & & & & & & 855 & \\
\hline TZR5 & & & & & & & 811 & \\
\hline TZR24 & & & & & & & & 614 \\
\hline TZR26 & & & & & & & & 633 \\
\hline TZR27 & & & & & & & & ,739 \\
\hline \multicolumn{9}{|c|}{ KMO ve Bartlett's: $0,717, \rho<0,000$} \\
\hline \multicolumn{9}{|c|}{ Toplam Açıklanan Varyans: $\% 64,640$} \\
\hline $\mathrm{Crc}$ & ach's Alpha: 0 , & & & & & & & \\
\hline
\end{tabular}


Ölçeğin yapı geçerliliğini test etmek amacıyla paket program ile Doğrulayıcı Faktör Analizi yapılmıştır. Doğrulayıcı Faktör Analizi neticesinde ölçeğin 8 boyutlu yapıya uyum sağlamadığı ve uyum iyiliği değerlerinin kabul edilebilir standartlarda olmadığı tespit edilmiştir. Bunun üzerine ilk olarak ifadelere ait standardize edilmiş regresyon ağırlıkları incelenmiştir. Düşük standardize edilmiş regresyon ağırlıklarına sahip oldukları belirlenen TRZ17 $(0,243)$ ve TRZ7 $(0,260)$ ifadeleri ölçekten çıkarılmıştır. Çıkarılan ifadelerin ardından modifikasyon işlemine geçilmiştir. Dağlı (2015: 211)'ya göre analiz neticesinde teorik yapıya bağlı kalmak koşuluyla modelin uyum iyiliğini geliştirmek için modifikasyon işlemi gerçekleştirilebilir. Modifikasyonlar, modelde orijinal olarak görülemeyen ancak ilgili düzenlemelerin yapılması yoluyla ki-kare miktarında meydana gelebilecek iyileşmeleri gösteren indekslerdir (Meydan ve Şeşen, 2015: 38). Bunun üzerine birbiri arasındaki kovaryans değerlerinin yüksek olduğu belirlenen TRZ6 ile TRZ8 (e2-e3), TRZ2 ile TRZ22 (e16-e19) ve TRZ 19 ile TRZ22 (e17-e19) ifadeleri arasında modifikasyon uygulanmıştır.

Modifikasyon işlemlerinin ardından tekrarlan nihai Doğrulayıcı Faktör Analiz (DFA) neticesinde verilerin ölçeğin 8 boyutlu yapısına uyum sağladığı tespit edilmiştir. Ölçeğin uyum iyiliği değerleri Tablo 3'te sunulmuştur (Gürbüz ve Şahin, 2016).

Tablo 3: Tedarik Zinciri Risk Ölçeği Uyum lyiliği Değerleri

\begin{tabular}{ccccccccccc}
\hline \multirow{2}{*}{ Ölçekler } & \multicolumn{2}{c}{} & & CMIN/ & GFI & AGFI & CFI & NFI & TLI & RMSEA \\
& $\mathbf{X}^{2}$ & df & DF $\leq 5$ & $\geq .85$ & $\geq .80$ & $\geq .90$ & $\geq .90$ & $\geq .90$ & $\leq .08$ \\
\hline Tedarik Zinciri Riskleri & 495,54 & 221 & 2,24 & .87 & .82 & .87 & .80 & .84 & .07 &
\end{tabular}

Uyum iyiliği değer aralıkları "kabul edilebilir " standartlara göre düzenlenmiştir (Gürbüz ve Şahin, 2016:337)

Uyum iyiliği değerleri incelendiğinde birçok uyum indeksinin kabul edilebilir değerlere sahip olduğunu görmek mümkündür. Buna karşın CFI değerinin eşik değerin altında olmasına rağmen 0,87 ile kabul edilebilir değer aldığını söylemek mümkündür. Ayyıldız ve Cengiz (2006: 77)' e göre yeni gelişmekte olan alanlarda oluşturulan bir modelin uyum iyiliği indekslerinin kritik limitlerin altında kalması normal karşılanmaktadır. Örneğin, kritik limiti en az 0.90 olan CFI' nın alacağı $0.85^{\prime}$ lik bir değer de kabul edilebilir niteliktedir. Ayrıca NFI ve TLI indekslerinin eşik değerlerin altında değerler almaları örneklem büyüklüğünden kaynaklanmakta ve ölçeğin uyumunu bozmamaktadır (Dağlı, 2015: 212).

Yapılan güvenilirlik analizi sonucunda Tedarik Zinciri Riskleri alt boyutlarına ait Cronbach's Alpha güvenilirlik katsayıları Tablo 4'te sunulmuştur.

Tablo 4: TZRÖ’ne Ait Güvenilirlik Katsayıları

\begin{tabular}{llllll}
\hline $\mathbf{N}$ & Faktörler & $(\boldsymbol{\alpha})$ & $\mathbf{N}$ & Faktörler & $(\boldsymbol{\alpha})$ \\
\hline 5 & Kapasite ve Tedarik Riskleri & $\mathbf{0 . 7 1 7}$ & 2 & Ürün Riskleri & $\mathbf{0 . 8 8 8}$ \\
3 & Tahmin ve Planlama Riskleri & $\mathbf{0 . 6 2 2}$ & 2 & Gecikme Riskleri & $\mathbf{0 . 6 8 3}$ \\
3 & Teknolojik Riskler & $\mathbf{0 . 8 6 6}$ & 3 & Envanter Riskleri & $\mathbf{0 . 5 3 5}$ \\
2 & Politik Riskler & $\mathbf{0 . 7 6 8}$ & 4 & Kesinti Riskleri & $\mathbf{0 . 6 1 0}$ \\
\hline Tedarik Zinciri Risk Ölçeği $(\alpha)$ değeri: $\mathbf{0 . 7 7 3}$ & & & & \\
\hline
\end{tabular}

Kalaycı (2008: 405)'ya göre güvenilirlik $0.60 \leq \alpha<0.80$ ise ölçeğin oldukça güvenilir olduğunu söylemek mümkündür. Tablo 3'te de görüldüğü ölçeği oluşturan alt boyutların güvenilir olduğunu söylemek mümkündür. 


\subsubsection{Lojistik Performans Ölçeği (LPÖ)}

Gaziantep OSB' de üretim faaliyetlerini sürdürmekte olan İşletmelerin lojistik performans düzeylerini ölçmek maksadıyla Bakan ve Şekkeli (2015) tarafından uygulanan güvenilirliği ve geçerliliği kanıtlanmış "Lojistik Performans Ölçeği (LPÖ)" nden yararlanılmıştır. Ölçek 15 sorudan oluşmakta ve $5^{\prime}$ li likert tipi ifadeleri içermektedir (1=Kesinlikle Katılmıyorum, $5=$ Kesinlikle Katılıyorum).

Ölçeğin yapısal geçerliliğini ölçmek amacıyla ilk olarak Keşfedici Faktör Analizi (KFA) yapılmıştır. Yapılan KFA sonucunda faktör yükleri 0.32'nin altında olan 5 ifade ölçekten çıkarılmıştır. Gürbüz ve Şahin (2016)'e göre faktör yükleri 0.32'nin altında kalan ifadelerin ölçekten çıkarılması gerekmektedir. Ardından yinelenen KFA sonucunda kalan 10 ifadenin tek boyut altında toplandığı görülmüştür. Örneklem yeterliliğinin belirlenmesi maksadıyla yapılan KMO ve Bartlett's testi sonucunda KMO değeri 0.719 ve Bartlett's testi anlamlı olarak bulunmuştur. (Dağlı, 2015: 205)’ya göre KMO değerinin 0.60 ve üzerinde bir değer alması faktör analizi için yeterlidir.

KFA neticesinde tek faktörden oluşan ve toplam varyansın \%30,442'siin açıklayan bir yapı elde edilmiştir. Elde edilen yapıya ait faktör yüklerinin 0,392 ile 0,654 arasında olduğu görülmüştür. Gürbüz ve Şahin (2016: 312)'e göre tek boyutlu ölçeklerde tüm faktörlerin açıkladığı toplam varyansın en az \%30 olması önerilmektedir.

Ölçeğin yapı geçerliliğini test etmek amacıyla Doğrulayıcı Faktör Analizi (DFA) yapılmıştır. DFA sonucunda ölçeğin tek boyutlu yapıya uyum sağlamadığı ve uyum iyiliği değerlerinin kabul edilebilir standartlarda olmadığı tespit edilmiştir. Bunun üzerine teorik yapıya bağlı kalınarak modelin uyum iyiliğini geliştirmek için modifikasyon işlemi gerçekleştirildi. Aralarında yüksek kovaryans bulunan LP1 ile LP2 (e1-e2) ve LP2 ile LP3 (e2-e3) ifadeleri arasında modifikasyon uygulanmıştır.

Modifikasyon işlemlerinin ardından tekrarlan nihai Doğrulayıcı Faktör Analiz (DFA) neticesinde verilerin ölçeğin tek boyutlu yapısına uyum sağladığı tespit edilmiştir. Ölçeğin uyum iyiliği değerleri Tablo 5'te sunulmuştur (Gürbüz ve Şahin, 2016).

Tablo 5: Lojistik Performans Ölçeği Uyum Iyiliği Değerleri

\begin{tabular}{ccccccccccc}
\hline \multirow{2}{*}{ Ölçekler } & \multicolumn{2}{c}{} & & CMIN/ & GFI & AGFI & CFI & NFI & TLI & RMSEA \\
\hline Lojistik Performans & 72,175 & 33 & 2,18 & .95 & .91 & .91 & .85 & .86 & .069 & \\
\hline
\end{tabular}

Uyum iyiliği değer aralıkları "kabul edilebilir " standartlara göre düzenlenmiştir (Gürbüz ve Şahin, 2016:337)

Uyum iyiliği değerleri incelendiğinde ölçeğin tek boyutlu yapıya uyum sağladığı görülmüştür. NFI ve TLI indekslerinin eşik değerlerin altında değerler almaları ölçeğin uyumunu bozmamakla birlikte veri büyüklüğünden kaynaklandığı söylenebilir (Dağlı, 2015: 212).

Yapılan güvenilirlik analizi sonucunda ölçeğin Cronbach's Alpha güvenilirlik katsayısı 0.74 olarak bulunmuştur. Kalaycı (2008: 405)’ya göre güvenilirlik $0.60 \leq \alpha<0.80$ ise ölçeğin oldukça güvenilir olduğunu söylemek mümkündür. 


\section{Bulgular}

\subsection{Demografik Bulgular}

Demografik bulgular kapsamında araştırmaya katılan işletmelerin faaliyet gösterdikleri sektör, işletmelerde çalışan personel sayıları ve işletmelerin faaliyet sürelerine ait özellikler tespit edilmiştir. Buna göre, anket uygulanan işletmelerin \%58,8'i tekstil, \%15,6'sı inşaat, $\% 11,2$ 'si gıda, \%6,4'ü kimya, \%3,4'ü mermer ve \%2,0'si makine sektöründe faaliyet göstermektedir.

İşletmelerin \%35,2'sinin 50-99 arası çalışana, \%20,4'ünün 1-49 arası çalışana, \%20,0'sinin 100-149 arası çalışana, yine \%16,8'inin 150-249 arası çalışana, \%5,2'sinin 250-499 arası çalışana ve son olarak \%2,4'ünün 500 ve üzeri çalışana sahip oldukları tespit edilmiştir.

Ayrıca araştırmaya katılan işletmelerin \%30,8'inin 6-10 yıl, \%24,8'inin 1-5 yıl, \%18,8'inin 11-15 yıl, \%13,6'sının 21 yıl ve üzeri faaliyet sürelerine sahip olduğu belirlenmiştir. Yine 16-20 yıl süreyle faaliyet gösteren işletmelerin oranları ise $\% 12,0$ olduğu tespit edilmiştir.

\section{2. Ölçeklerde Yer Alan Önermelere Ait Bulgular}

\subsubsection{Tedarik Zinciri Risk Ölçeği'ne Ait Bulgular}

Araştırma kapsamında işletmelere uygulanan tedarik zinciri risk ölçeğinde yer alan boyutlara ilişkin ortalama ve standart sapma değerleri Tablo 6 'da sunulmuştur.

Tablo 6: TZR Ölçeği' ne Ait Alt Boyutların Ortalama ve Standart Sapma Değerleri

\begin{tabular}{llr}
\hline Tedarik Zinciri Riskleri & Ort. & St. Sapma \\
\hline Faktör 1: Kapasite ve Tedarik Riski & 1,50 &, 392 \\
Faktör 2: Teknolojik Riskler & 1,66 &, 578 \\
Faktör 3: Ürün Riski & 1,97 &, 879 \\
Faktör 4: Tahmin ve Planlama Riski & 1,95 &, 586 \\
Faktör 5: Gecikme Riski & 2,16 &, 574 \\
Faktör 6: Kesinti Riski & 2,62 &, 555 \\
Faktör 7: Politik Riskler & 3,48 &, 688 \\
Faktör 8: Envanter Riski & 2,10 &, 583 \\
\hline TOPLAM & $\mathbf{2 , 1 8}$ & \\
\hline
\end{tabular}

Tablo 6 incelendiğinde işletmelerin en yüksek düzeyde algıladıkları riskin "politik riskler" olduğu görülmektedir $(3,48)$. Özelikle yıllardır gerek Suriye'de ve gerekse Orta Doğu'da yaşanan savaş ve belirsizlik ortamı, ihracatının büyük bölümünü bu pazarlara yapan Gaziantep OSB' deki işletmeler açısından büyük risk teşkil etmektedir. Yine yaşanan bu gelişmelerin özelikle gümrüklerde ve sipariş iptallerinde yarattığı olumsuzluklar kesinti risklerinin de işletmeler tarafından hissedilmesine yol açmıştır $(2,62)$. Buna karşın işletmelerin kapasite ve tedarik riskleri $(1,50)$, teknolojik riskleri $(1,66)$, ürün riski $(1,97)$ ve tahmin ve planlama risklerini $(1,95)$ düşük düzeyde algıladıkları sonucuna ulaşılmıştır. Elde edilen sonuçlar dikkate alındığında işletmelerin tedarik zinciri risklerinin düşük düzeyde hissettiklerinin söylemek mümkün olacaktır. 


\subsubsection{Lojistik Performans Ölçeği’ne Ait Bulgular}

İşletmelerin lojistik performansları ile ilgili önermeleri ait bulgular Tablo 7'de belirtilmiştir.

Tablo 7: Lojistik Performans Ölçeği' ne Ait Önermelerin Ortalama ve Standart Sapma Değerleri

\begin{tabular}{llr}
\hline \multicolumn{1}{c}{ Lojistik Performans } & Ort. & St. Sapma \\
\hline LP1.Firmamızın tedarik süresi kısadır. & 4,26 &, 653 \\
LP2.Firmamızda müşteri tatmin oranı yüksektir. & 4,14 &, 630 \\
LP3.Firmamızda müşteriyi elde tutuma başarısı yüksektir & 4,08 &, 712 \\
LP4.Firmamızda müşteri şikâyet oranı düşüktür. & 4,17 &, 716 \\
LP5.Firmamızda özel ya da rutin dışı ürünler üretilir. & 4,15 &, 718 \\
LP6.Firmamız beklenmedik olayların üstesinden gelir. & 4,21 &, 709 \\
LP7.Firmamızda müşterilere hızlıca yanıt verilir. & 4,17 &, 733 \\
LP8.Firmamızda genel işletme maliyetleri düşüktür. & 3,98 &, 781 \\
LP9.Firmamızda tesis/ekipman/işgücü kullanım oranı yüksektir. & 4,18 &, 721 \\
LP10.Firmamız siparişlerin tam zamanında teslimi konusunda katıdır. & 4,36 &, 657 \\
\hline \multicolumn{1}{c}{ TOPLAM } & 4,17 & \\
\hline
\end{tabular}

Tablo 7 incelendiğinde çalışmaya katılan işletmelerin lojistik performans düzeylerinin yüksek olduğu sonucuna ulaşılmaktadır. Özelikle siparişlerin tam zamanında teslimi noktasındaki işletmelerin başarılı oldukları görülmektedir $(4,36)$. Yine işletmelerdeki tedarik sürelerinin kısa olması $(4,26)$ ve beklenmeyen olayların üstesinden gelebilecek esnekliğe sahip olmaları lojistik performanslarını artıran diğer noktalardır.

\subsection{Yapısal Eşitlik Modeli Analizi}

Çalışmanın bu aşamasında Gaziantep Organize Sanayi Bölgesi'nde üretim faaliyetlerini sürdürmekte olan işletmelerin algıladıkları tedarik zinciri risklerinin lojistik performansları üzerindeki etkileri alt boyutlarıyla ortaya konulacaktır. Bu kapsamda oluşturulan hipotezlerin test edilmesi maksadıyla faktör ve regresyon analizlerinin birleşiminden oluşan ve gözlenen ve gözlenmeyen değişkenleri içeren modellerin test edilmesinde kullanılan Yapısal Eşitlik Modeli'nden yararlanılmıştır. Bu kapsamda oluşturulan yapısal model Şekil 2'de, modele ait uyum iyiliği değerleri Tablo 7'de ve yapısal modele ait regresyon ağırlıkları Tablo 8'de sunulmuştur.

Şekil 2: Araştırmaya Ait Yapısal Model

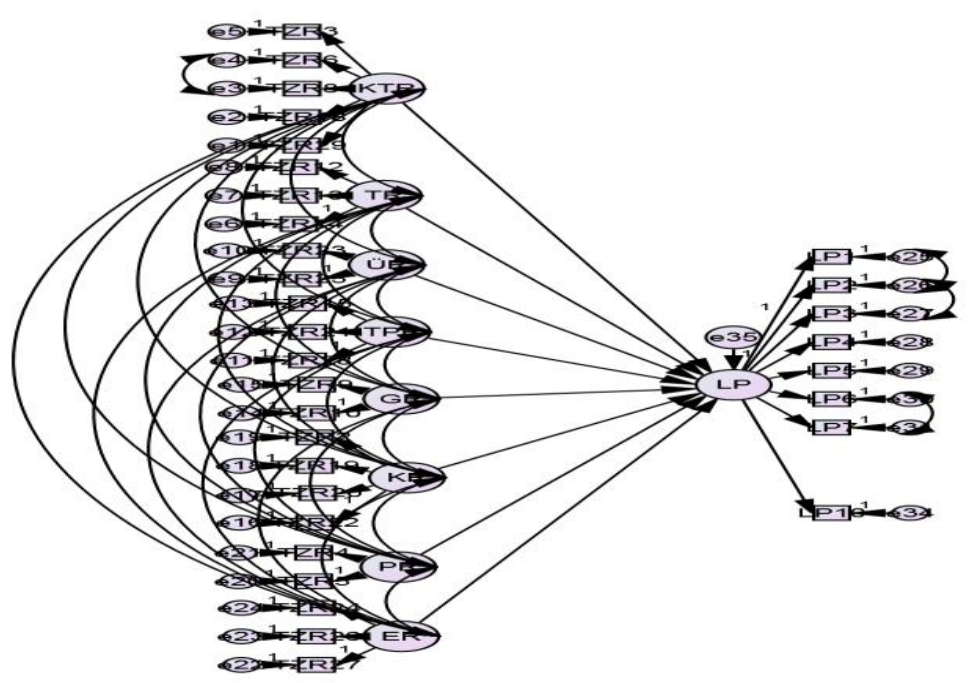


YEM, test edilen modelin toplanan veri seti ile uyumlu olup olmadığını belirlemek için çeşitli uyum iyiliği indeksleri sunmaktadır. Kurulan yapısal modelin test edilebilmesi için öncelikle modele ait uyum iyiliği değerlerine bakılmıştır. Araştırma modelinin uyum iyiliği değerlerinin kabul edilebilir standartlarda olmadığı tespit edilmiştir. Bunun üzerine ilk olarak ifadelere ait standardize edilmiş regresyon ağırlıkları incelenmiştir. Düşük standardize edilmiş regresyon ağırlıklarına sahip oldukları belirlenen LP8 ile LP9 ifadeleri modelden çıkarılmıştır. Çıkarılan ifadelerin ardından modelin uyum iyiliği değerlerini iyileştirmek maksadıyla modifikasyon işlemine geçilmiştir. Modifikasyonlar, modelde orijinal olarak görülemeyen ancak ilgili düzenlemelerin yapılması yoluyla ki-kare miktarında meydana gelebilecek iyileşmeleri gösteren indekslerdir (Meydan ve Şeşen, 2015: 38). Bunun üzerine birbiri arasındaki kovaryans değerlerinin yüksek olduğu belirlenen TZR6 ile TZR8 (e3-e4), LP1 ile LP2 (e25-e26), LP2 ile LP3 (e26e27) ve LP6 ile LP7 (e30-e31) ifadeleri arasında modifikasyon uygulanmıştır.

Tablo 8: Araştırma Modeli Uyum lyiliği Değerleri

\begin{tabular}{llllllllll}
\hline & & & CMIN/ & GFI & AGFI & CFI & NFI & TLI & \multicolumn{2}{c}{ RMSEA } \\
Ölçekler & $\mathbf{X}^{2}$ & $\mathrm{df}$ & $\mathrm{DF} \leq 5$ & $\geq .85$ & $\geq .80$ & $\geq .90$ & $\geq .90$ & $\geq .90$ & $\leq .08$ \\
\hline Model & 725,374 & 424 & 1,71 & .85 & .81 & .88 & .76 & .86 & .05 \\
\hline
\end{tabular}

Uyum iyiliği değer aralıkları "kabul edilebilir "standartlara göre düzenlenmiştir (Gürbüz ve Şahin, 2016:337).

Uyum iyiliği değerleri incelendiğinde birçok uyum indeksinin kabul edilebilir değerlere sahip olduğunu görmek mümkündür. Buna karşın CFI değerinin eşik değerin altında olmasına rağmen 0,88 ile kabul edilebilir değer aldığını söylemek mümkündür. Ayyıldız ve Cengiz (2006: 77)' e göre CFI' nın alacağı 0.85 ve üzerinde bir değer kabul edilebilir niteliktedir. Ayrıca NFI ve TLI indekslerinin eşik değerlerin altında değerler almaları örneklem büyüklüğünden kaynaklanmakta ve modelin uyumunu bozmamaktadır (Dağlı, 2015: 212). Sonuç olarak ulaşılan uyum iyiliği değerleri kurulan yapısal modelin veri ile uyumlu olduğunu göstermektedir. Bu doğrultuda araştırma hipotezlerinin YEM ile test edilmeye uygun olduğu sonucuna varılmıştır.

Tablo 9: Yapısal Eşitlik Modeli Regresyon Ağırlıkları

\begin{tabular}{|c|c|c|c|c|c|c|}
\hline Test Edilen Yol & & & Tahmin & Std. Hata & Kritik Oran & Anlamlılık \\
\hline $\begin{array}{l}\text { Kapasite ve } \\
\text { Tedarik Riski }\end{array}$ & $\rightarrow$ & $\begin{array}{l}\text { Lojistik Perfor- } \\
\text { mans }\end{array}$ &,- 170 & .087 & 1,967 & 0,04 \\
\hline Teknolojik Riskler & $\rightarrow$ & $\begin{array}{l}\text { Lojistik Perfor- } \\
\text { mans }\end{array}$ &,- 023 & ,038 &,- 595 & 0,55 \\
\hline Ürün Riski & $\rightarrow$ & $\begin{array}{l}\text { Lojistik Perfor- } \\
\text { mans }\end{array}$ &,- 020 & ,020 &,- 968 & 0,33 \\
\hline $\begin{array}{c}\text { Tahmin ve Plan- } \\
\text { lama Riski }\end{array}$ & $\rightarrow$ & $\begin{array}{l}\text { Lojistik Perfor- } \\
\text { mans }\end{array}$ &,- 011 & ,056 &,- 201 & 0,84 \\
\hline Gecikme Riski & $\rightarrow$ & $\begin{array}{l}\text { Lojistik Perfor- } \\
\text { mans }\end{array}$ & -079 & ,040 & $-1,964$ & 0,04 \\
\hline Kesinti Riski & $\rightarrow$ & $\begin{array}{l}\text { Lojistik Perfor- } \\
\text { mans }\end{array}$ & 007 & ,068 & ,097 & 0,92 \\
\hline Politik Riskler & $\rightarrow$ & $\begin{array}{l}\text { Lojistik Perfor- } \\
\text { mans }\end{array}$ &,- 032 & ,033 & -,979 & 0,32 \\
\hline Envanter Riski & $\rightarrow$ & $\begin{array}{l}\text { Lojistik Perfor- } \\
\text { mans }\end{array}$ &,- 088 & 103 &,- 856 & 0,39 \\
\hline
\end{tabular}

Tedarik zinciri risklerinin lojistik performans üzerindeki etkisini belirlemek amacıyla oluşturulan yapısal modele ait regresyon ağırlıkları Tablo 9' da belirtilmiştir. Buna göre Tedarik Zinciri Riskleri'nden "Kapasite ve Tedarik Riski" ( $\beta=-, 170, p=0.04<0.05)$ alt boyutu ve "Gecikme Riski" 
$(\beta=-, 079, p=0.04<0.05)$ alt boyutunun lojistik performans üzerinde negatif yönlü ve anlamlı etkisinin olduğu sonucu ortaya çıkmıştır. Buna karşın "Teknolojik Riskler”, "Ürün Riski”, "Tahmin ve Planlama Riski", "Kesinti Riski", "Politik Riskler" ve "Envanter Riski" alt boyutlarının lojistik performans üzerinde anlamlı etkilerini olmadığı sonucuna ulaşılmıştır. Bu sonuçlara göre kapasite ve tedarik risklerindeki bir birimlik azalma lojistik performans üzerinde \%17'lik bir artışa, gecikme risklerindeki bir birimlik azalma ise lojistik performans üzerinde \%7,9 'luk bir artışa yol açacağı söylenebilir.

Bu durumda;

Tedarik zinciri risklerinin lojistik performans üzerindeki etkilerini belirlemek amacıyla oluşturulan $\mathrm{H} 1$ ve $\mathrm{H} 5$ hipotezleri kabul edilirken, $\mathrm{H} 2, \mathrm{H} 3, \mathrm{H} 4, \mathrm{H} 6, \mathrm{H} 7$ ve $\mathrm{H} 8$ hipotezleri desteklenmemiştir.

\section{Sonuç ve Öneriler}

Bu çalışmada, Gaziantep OSB'lerde faaliyet gösteren üretim işletmelerinin algıladıkları tedarik zinciri risklerinin lojistik performansları üzerinde nasıl bir etkiye sahip olduğunu belirlemek maksadıyla yapılmıştır. Bu doğrultuda tabakalı örneklem tekniğinden yararlanılarak Gaziantep Organize Sanayi Bölgeleri'nde faaliyet gösteren 274 üretin işletmesine anket uygulanmıştır. Elde edilen veriler SPSS ve AMOS programları kullanılarak analiz edilmiştir.

Çalışmanın amacına yönelik olarak oluşturulan hipotezlerin kapsamını; tedarik zinciri risklerinin lojistik performansı negatif ve anlamlı etkileyip etkilemediğini oluşturmaktadır. Elde edilen bulgular doğrultusunda oluşturulan hipotezlerin ispatı amaçlanmıştır.

Araştırmaya katılan işletmelere ait demografik bulgular incelendiğinde işletmelerin $\% 58,8$ 'inin tekstil sektöründe faaliyet gösterdiği görülmektedir. Bu sonuç, Gaziantep OSB'lerde faaliyet gösteren işletmelerin sektörel dağılımıyla da uygunluk göstermektedir. İpek Yolu Kalkınma Ajansı'ndan alınan bilgilere göre Gaziantep OSB'lerde faaliyet gösteren işletmelerin sektörel dağılımlarında tekstil sektörü ilk sırayı almaktadır (www.ika.org.tr). Yine araştırmaya katılan işletmelerin büyük bir kısmının 50-99 arası çalışana sahip olduğu ve 6 ile 10 yıl arasında bir faaliyet süresine sahip olduğu görülmektedir.

Tedarik zinciri risklerinin lojistik performans üzerindeki etkileri oluşturulan Yapısal Eşitlik Modeli ile analiz edilmiştir. YEM analizi sonucunda tedarik zinciri riskleri alt boyutlarında "Kapasite ve Tedarik Riski" ve "Gecikme Riski" alt boyutlarının lojistik performans negatif ve anlamlı bir şekilde etkilediği tespit edilmiştir. Buna göre kapasite ve tedarik riskinde meydana gelecek bir birimlik azalış lojistik performansı \%17 oranında artıracaktır $\beta$ (-.170). Yine gecikme risklerindeki bir birimlik azalış lojistik performansın \%7,9 oranında artmasına neden olacaktır. Bununla birlikte teknolojik riskler, ürün riskleri, tahmin ve planlama riski, kesinti riski, politik riskler ve envanter riskleri alt boyutlarının lojistik performans üzerinde anlamlı etkilerinin olmadığı sonucuna ulaşılmıştır.

Hendricks ve Singhal (2003) yaptıkları çalışmada tedarik zinciri risklerinin faaliyet gelirleri ve varlık getirilerinin yanı sıra finansal performans ölçüleri üzerinde negatif etkilerinin olduğunu ve bununda işletmelerin taşıma ve depolama gibi diğer faaliyetlerini olumsuz etkilediği sonucuna ulaşmışlardır (Haksöz vd., 2014: 308).

Kevin Hendricks'in 1989-2000 yılları arasında 800 firma üzerinde yaptığı araştırma tedarik zinciri risklerinin işletmelerin finansal ve finansal olmayan performansları üzerinde nasıl bir etki yaptığını ortaya koymuştur. Çalışma sonucunda, tedarik zinciri risklerinin işletmelerin gerek finansal gerekse de pazarlama, lojistik, MiY gibi finansal olmayan performansları üzerin- 
de negatif etkisinin olduğu belirlenmiştir. Dünya çapında 600 işletme yöneticisinin katıldığı bir başka araştırmaya göre tedarik zinciri risklerinin diğer tüm risklerden daha fazla oranda işletme gelirlerini etkileme potansiyeli olduğu sonucunu ortaya çıkarmıştır (Akkan, 2014: 27).

Özellikle Suriye başta olmak üzere Orta Doğu'da yaşanan savaş ve iç çatışmalar bu bölgeye sınır olan ve ihracatının çok büyük bir kısmını bu bölgeye gerçekleştiren Gaziantep OSB'lerdeki üretim işletmelerini olumsuz etkilemiştir. Gümrük kapılarında yaşanan uzun bekleme süreleri teslimatta gecikmelere neden olmakta ve bu olayın sık yaşanmasıyla birlikte ani sipariş iptalleri ortaya çıkmaktadır. Bu durum, gecikme ve kapasite risklerinin artmasına neden olabilmektedir. Bölgede faaliyet gösteren işletmeler bu riskleri ortadan kaldırabilmek adına özellikle deniz yolu taşımacılığına yönelmiş, bununla birlikte Suriye ve Kuzey Irak'ta depo kiralama yoluna giderek bölgeye yapılacak sevkiyatların hızlanması noktasında tedbirler almışlardır. İsletmelerin attıkları bu adımlar kapasite ve gecikme risklerinin azalmasına ve lojistik faaliyetlerin en yüksek performansla yerine getirilmesine zemin hazırlamıştır. Bölgede faaliyet gösteren işletmelerin teknolojik gelişmeler noktasında zamanında hamlelerle bu riskleri bertaraf ettiklerini, yine stoksuz çalışarak başta moda etkisinden kaynaklı ürün risklerini ve envanter risklerini en aza indirdiklerini söylemek mümkündür.

İşletmelerin sıkı sıkıya bağı oldukları tedarik zinciri yapısında karşılaşılması muhtemel risklerin belirlenmesi ve bu risklerin lojistik süreçler üzerindeki etkilerinin gözlemlenmesi noktasında çalışma önem taşımaktadır. İşletmelerin karşılaşılması muhtemel riskleri önceden görüp gerekli tedbirleri almaları bu risklerin olumsuz etkilerinin tamamen ortadan kaldıracağı gibi azaltılmasında büyük önem arz etmektedir. Ayrıca çalışma konu ile ilgili literatürdeki boşluğu doldurması açısından da önem taşımaktadır. Tedarik zinciri risklerinin daha geniş boyutlarla ele alınması ve farklı bölgeler açısından incelenmesi ileriki çalışmalar için önerilmektedir. 


\section{Kaynaklar}

Akkan, Erdem (2014), "Tedarik Zincirinde Risk Kaynakları Algıları, Risk Yönetim Faaliyetleri Ve Performans Ilişkisi: Mersin'de Faaliyet Gösteren Perakende Işletmeler Üzerine Bir Araştırma", Yayınlanmamış Doktora Tezi, Çukurova Üniversitesi, Adana.

Ayyıldız, Hasan. ve Cengiz, Ekrem (2006), “Pazarlama Modellerinin Testinde Kullanılabilecek Yapısal Eşitlik Modeli (YEM) Üzerine Kavramsal Bir İnceleme”, Süleyman Demirel Üniversitesi Iktisadi Idari Bilimler Fakültesi Dergisi. C.11, S. 1, 63-84.

Bakan, İsmail. ve Şekkeli, Zümrüt (2015),"Lojistik Koordinasyon Yeteneği, Lojistik İnovasyon Yeteneği Ve Müşteri İlişkileri (MiY) Yeteneği İle Rekabet Avantajı Ve Lojistik Performans Arasındaki İlişki: Bir Alan Araştırması”, Karamanmaraş Sütçü Imam Üniversitesi I.i.B.F. Dergisi, C.5, S. 2, 39-68.

Bayraktutan, Yusuf ve Özbilgin, Mehmet (2015), "Lojistik Maliyetler Ve Lojistik Performans Ölçütleri”, Maliye Araştırmaları Dergisi, C.1, S. 2, 95-112.

Büyüközkan, Gülçin (2008), “Tedarik Zincirinde Risk Yönetimi”, Lojistik Dergisi, No.8, 1-21.

Chatzidimitriou, Kyriakos, Symeonidis, Andreas, Kontogounis, oannis. and Mitkas, Pericles (2008), "Agent Mertacor: A Robust Design For Dealing With Uncertainty And Variation İ SCM Environments", Expert Systems with Applications, No. 35. 591-603.

Chopra, S. ve Sodhi, M.S. (2004). Managing risk to avoid supply chain breakdown. MIT Sloan Management Review, 46(1). 53-61.

Dağlı, Abidin (2015), “Örgütsel Muhalefet Ölçeğinin Türkçe'ye Uyarlanması: Geçerlilik Ve Güvenirlik Çalışması”, Elektronik Sosyal Bilimler Dergisi, C.14, S.53, 198-218.

Demirkol, İsa, Ünğan, Mustafa Cahit ve Ayanoğlu, Murat (2015), "Tedarik Zinciri Risklerinin İşletme Performansına Etkisi: Otomotiv Sektöründe Bir Uygulama", İşletme Bilimi Dergisi. C.3, s. 1, 20-37.

Dereli, A. (2014). Tedarik riskleri altında tedarikçi seçiminin Bayes ağlarıyla modellenmesi. Yayınlanmamış yüksek lisans tezi, İstanbul Teknik Üniversitesi, İstanbul.

Derici, Onur, Tüysüz, Zekeriya ve Sarı, Aydın (2007), "Kurumsal Risk Yönetimi Ve Sayıştay Uygulaması”, Sayıştay Dergisi, Sayı 65, 151-172.

Ellis, Scott , Henry, Raymond and Shockley, Jeff (2010), "Buyer Perceptions Of Supply Disruption Risk: A Behavioral View And Empirical Assessment", Journal of Operations Management, No.28, 34-46.

Eriksson, Kent, Jonsson, Sara, Lindberg, Jessica and Lindstrand, Angelika (2014), “Modeling Firm Specific Internationalization Risk: An Application To Banks' Risk Assessment In Lending To Firms That Do International Business", International Business Review, Vol. 23, No. 6, 1074- 1085.

Fitrianto, Achmad Room and Hadi, Suryadi (2012), "Supply Chain Risk Management in Shrimp Industry Before And During Mud Volcano Disaster: An İnitial Concept", Procedia - Social and Behavioral Sciences, 65, 427-435.

Gaziantep Organize Sanayi Bölgesi. (2016). http://www.gaosb.org/index.php/hakkimizda/. Erişim Tarihi: 10.01.2018

Ghagde, Abhijeet., Dani, Samir and Kalawsky, Roy (2012), "Supply Chain Risk Management: Present And Future Scope", Inretnational Journal of Logistics Management, Vol.23, No.3, 313-339.

Gürbüz, Sait ve Şahin, Faruk (2016), Sosyal Bilimlerde Araştırma Yöntemleri Felsefe-Yöntem-Analiz. Ankara: Seçkin Yayınevi.

Haksöz, Ç. , Seshadri, S. ve Iyer, A.V. (2014). İpek yolunda tedarik zinciri yönetimi: Strateji, performans ve risk, İstanbul: Scala Yayıncılık.

Helvacı, Mehmet Akif (2012), "Performans Yönetimi Sürecinde Performans Değerlendirmenin Önemi”, Ankara Üniversitesi Eğitim Bilimleri Fakültesi Dergisi, C.35, S.1-2, 155-169.

Ishtiaqlshaq, Muhammad, Khaliq, Waseem, Hussain, Nazia. and Waqas, Muhammad (2012), "A Review on Triple-a Supply Chain Performance", School of Doctoral Studies (European Union) Journal, 89-94.

İpek Yolu Kalkınma Ajansı, https://www.ika.org.tr/Sanayi-icerik-65.html, Erişim Tarihi: 10.01.2018

Jüttner, Uta, Peck, Helen and Christopher, Martin (2003), "Supply Chain Risk Management: Outlining An Agenda For Future Research", International Journal of Logistics : Research \& Applications, Vol. 6, No. 4, 197-210.

Kalaycı, Şeref (2008), SPSS Uygulamalı Çok Değişkenli Istatistik Teknikleri, 3. Baskı, Ankara: Asil Yayınevi. 


\section{Eskişehir Osmangazi Üniversitesi IïBF Dergisi}

Kayabaşı, Aydın. ve Özdemir, Ali (2008), "Üretim İşletmelerinde Lojistik Yönetimi Faaliyetlerinde Performans Yönetimine Bakış: Beklenti-Fayda Farkı Analizi Uygulaması", Atatürk Üniversitesi Iktisadi ve Idari Bilimler Fakültesi Dergisi, C.22, S.1, 195-209.

Kırılmaz, Oğuzhan (2014) "Tedarik Zinciri Şebekesinde Risk Yönetimi: Otomotiv Endüstrisinde Bir Uygulama”, Yayınlanmamış Doktora Tezi, Gazi Üniversitesi, Ankara.

Meydan, Cem Harun ve Şeşen, Harun (2015), Yapısal Eşitlik Modellemesi: AMOS Uygulamaları, 2.Baskı, Ankara: Detay Yayıncilık.

Narasimhan, Ram and Talluri, Sirinivas (2009), "Perspectives On Risk Management In Supply Chains", Journal of Operations Management, Vol. 27, No. 2, 114-118.

Özgüner, Zeynep (2017), "Lojistik Faaliyetlerin Süreçsel Etkinliğinde Rol Oynayan Değişkenlerin İşletme Performansına Etkisinde Lojistik Performansın Aracılık (Mediatör) Rolü”, Yayımlanmamış Doktora Tezi, Hasan Kalyoncu Üniversitesi Sosyal Bilimler Enstitüsü, Gaziantep.

Paksoy, Turan , Güleş, Hasan. Kürşat, Altıparmak, F., (2003), "Tedarik Zinciri Yönetiminde Dağıtım Ağlarının Tasarımı ve Eniyilemesi: Çok Aşamalı Karma Tam Sayılı Bir Doğrusal Programlama Modeli”, Dokuz Eylül Üniversitesi Işsletme Fakültesi Dergisi, C. 4, S. 2, 1-25.

Salkın, Sultan Ceren (2014), “Geleneksel Ve E-Ticaret Tedarik Zinciri Risk Yönetiminin Sistem Dinamiği Yaklaşımıyla Modellenmesi", Yayınlanmamış Yüksek Lisans Tezi, İstanbul Teknik Üniversitesi, İstanbul.

Sekaran, Uma (1992), Research Methods For Business: A Skill Building Approach. Second Edition. John Wiley \& Sons.

Sezen, Bülent, Yılmaz, C. ve Gezgin, G. (2002), “Lojistik İşlevinin Pazarlama Ve Üretim Birimleri Arasındaki Bağlayıcı Rolü Ve İşletme Performansı Üzerindeki Etkileri” Dokuz Eylül Üniversitesi i.i.B.F. Dergisi, C.17, S. 2, 133-146.

Wagner, Stephan and Neshat, Nikrouz (2010), “Assessing The Vulnerability Of Supply Chains Using Graph Theory", International Journal of Production Economics, No. 26. 121-129.

World Economic Forum. (2012). New Models For Addressing Supply Chain And Transport Risk.

Zsidisin, George and Wagner, Stephan (2008), "Supply Risk Perceptions And Practices: An Exploratory Comparison Of German And US Supply Management Professionals", International Journal of Technology, Policy and Management, Vol.8, No.4, 401-419. 